\section{Lembaran Sejarah}

\title{
Suara "Merah" |lbu Kota: Geliat Politik Partai Komunis Indonesia Comite Djakarta Raya
}

\section{SATRIONO PRIYO UTOMO}

Universitas Indonesia

\begin{abstract}
After the rise of nationalist movement, the Indonesian Communist Party (PKI) was one of the disciplined organizations in Indonesia. PKI has become the primary example in understanding how organized movements transformed after Indonesia's independence. Ruth McVey's assessment that the PKI as being the most organized organization is not excessive. When the PKI was revamped in the early 1950, it conducted political education through translation and publication work. In various cities they conducted research in order to understand the social contexts to determine the party's political programs. In various cities they did research that had a purpose to understand the social context in order to determine the party's political program, including one of the important areas was Jakarta. Politic contestation in Jakarta was not always interpreted with the struggle for mastery hegemonic discourse. Although in the period of 1950-1965 the discourse struggle was involved the three big powers, nationalists, Islamist and communists. This idea was just organized by chief of these organizations that was located in Jakarta. In addition, Jakarta has major problems in meeting the everyday needs of its population. Thus, the existence of PKI in Jakarta does not always play practical issues, but also advocated populist issues as well.
\end{abstract}

\begin{abstract}
Abstrak
Selepas masa pergerakan nasional, PKI menjadi salah satu organisasi di Indonesia yang lengkap dan displin. PKI menjadi pusat perhatian bagi mereka yang ingin melihat bagaimana cara kerja organisasi-organisasi pergerakan pasca-kemerdekaan. Sehingga tidak berlebihan apabila Ruth McVey mengatakan bahwa PKI adalah organisasi yang tahu caranya berorganisasi. Saat kembali membangun partai di awal 1950-an yang pertama kali dilakukan oleh PKI adalah pendidikan politik melalui kerja-kerja penerbitan dan penerjemahan. Di berbagai daerah mereka melakukan riset yang bertujuan untuk memahami konteks sosial masyarakat guna menentukan program politik partai, termasuk salah satu wilayah yang penting adalah Jakarta. Kontestasi politik di Jakarta tidak selalu dapat dimaknai dengan perebutan hegemoni penguasaan wacana nasional. Meski dalam periode politik Indonesia 1950-1965 pertarungan wacana terjadi di antara tiga kekuatan besar yaitu nasionalis, agama, dan komunis. Hal itu hanya diorganisir oleh pimpinan pusat organisasi-organisasi tiga kekuatan besar di Indonesia yang pusat organisasinya berkedudukan di Jakarta. Jakarta juga didera persoalan memenuhi kebutuhan hidup sehari-hari. Oleh karena itu, keberadaan PKI di Jakarta dituntut untuk tidak selalu memainkan isu politik praktis, tapi juga melakukan advokasi isu-isu kerakyatan.
\end{abstract}

\section{Keywords:} PKI; Jakarta; politics; populist; life necessities 


\section{Pengantar}

Memaknai sejarah Indonesia sesungguhnya bukan perkerjaan mudah, terlebih menuliskannya. Bila dipahami, setiap patahan waktu dalam sejarah Indonesia terdapat detail yang menggugat rasa kemanusiaan pembaca dan penulis. Baik dalam periode feodal maupun kolonial, selalu ada penderitaan yang hidup berdampingan dengan kejayaan. Di saat yang bersamaan, sejarah hadir sebagai sebuah pintu masuk bagi rasa kemanusiaan untuk menyambut masa depan.

Rasa kemanusiaan itu kembali menggugat, ketika kita diajak untuk melihat kejadian-kejadian setelah peristiwa 1 Oktober 1965. Berbagai rekaman-rekaman penelitian yang dilakukan oleh sarjana asing dan Indonesia menyatakan bahwa telah terjadi apa yang disebut oleh Robert Cribb sebagai massacre. Sehingga kita sampai pada satu buah kesadaran bahwa ada suatu peristiwa dalam sejarah Indonesia yang merekam pembunuhan massal terhadap manusia atas tuduhan tanpa adanya proses peradilan. Korban yang dibunuh kebanyakan berasal dari para simpatisan, calon anggota, anggota Partai Komunis Indonesia (PKI).

Lantas, siapakah PKI? Apabila mengikuti propaganda Orde Baru, yang terbayang ialah semacam monster dengan kekuatan dan kekuasaan yang luar biasa-27 juta orang tergabung bersama dalam satu organisme besar, ibarat sel-sel di dalam tubuh seluruhnya dikuasai oleh satu pusat otak: Politbiro. Dalam bahasa Orde Baru, PKI selalu tampak sebagai satu hal: "PKI kejam", "PKI sadis', dan sejenisnya. Propaganda rezim Suharto menggambarkan PKI sebagai kelompok yang terorganisir dengan sangat baik, sehingga mereka mampu melakukan pencapaian-pencapaian luar biasa, lebih dari itu PKI bukanlah partai politik biasa. Entah bagaimana, Politbiro secara rahasia dapat memerintahkan semua jutaan anggotanya di semua daerah di Indonesia untuk menggali kuburan massal, mengumpulkan alat pencongkel mata, kemudian menyiapkan sebuah pemberontakan. Tidak ada seorang pun di negara ini, bahkan seorang pun agen intelijen tentara yang mengetahui tentang rencana pemberontakan ini.1

Di dalam kondisi yang seperti ini, tidak mungkin untuk memahami sejarah PKI sebagai sebuah organisasi secara tersendiri, sebab para tokohnya sudah terlibat dalam pembentukan republik ini di masa-masa revolusi. Organisasi-organisasi massa PKI seringkali hadir mewarnai dinamika politik baik di tingkat lokal maupun nasional. Tatkala republik sedang bergerak menuju revolusi, massa PKI-lah yang sebagian memenuhi rapat-rapat umum. Bahkan setelah republik berdiri, massa PKI terus merawat jalannya revolusi dengan aksi-aksi politik di jalanan, salah satunya berupa tuntutan untuk melakukan nasionalisasi aset asing. Tentu narasi-narasi yang telah

1) Dituliskan oleh John Roosa dalam kata pengantar yang diberikan untuk artikel yang ditulis Ruth T. McVey, Mengajarkan Modernitas: PKI Sebagai Sebuah Lembaga Pendidikan, IndoPROGRESS, 2016 
disebutkan ini sia-sia, sebab apabila ada orang yang berani menulis tentang PKI, mau tidak mau dia akan dituduh sebagai "pendukung PKI". Akibatnya, masyarakat Indonesia terbiasa memperlakukan PKI seperti hantu dan sejarahnya adalah misteri. Apabila kenyataannya seperti itu, patut terlontar pertanyaan, apakah mereka yang berjumlah jutaan tergabung dalam PKI bukanlah manusia?

Sejarah tidak akan mungkin hadir tanpa ada manusia. Itulah keyakinan yang dianut oleh banyak orang yang belajar sejarah. Oleh karena itu, telah banyak sarjana asing dan Indonesia yang memperlakukan PKI sebagai manusia. Salah satunya adalah Ruth McVey yang mendokumentasikan elan perjalanan organisasi buruh dan petani dalam karya termasyhurnya The Rise of Indonesian Communism. Para sarjana sejarah PKI, Rex Mortimer berpendapat bahwa mereka kagum atas kualitas para pemimpin PKI dan kader-kadernya, meliputi: kemampuan berpolitik; perhatian yang sangat besar bagi kepentingan para pekerja, buruh pabrik, petani miskin dan para buruh tani; evaluasi realistis terhadap situasi dan kondisi para pekerja; serta relatif bersihnya kelompok ini dari noda korupsi yang membuat ekonomi Indonesia ambruk pada 1960-an (Satriono Priyo Utomo, 2016: 24).

Selepas masa pergerakan nasional, PKI menjadi salah satu organisasi di Indonesia yang sangat lengkap dan displin. PKI pun menjadi pusat perhatian bagi mereka yang ingin melihat bagaimana cara kerja organisasi-organisasi pergerakan pasca-kemerdekaan. Sehingga tidak berlebihan apabila Ruth McVey sebagaimana yang dikutip Daniel Lev dan Tim Lindsey (2008: 160) mengatakan bahwa PKI tahu cara berorganisasi. Saat kembali membangun partai di awal 1950-an, yang pertama kali dilakukan PKI adalah pendidikan politik melalui kerja penerbitan dan penerjemahan.

Mereka menggagas beridirinya Yayasan Pembaruan sebagai wadah untuk menerbitkan dan mempublikasikan tulisan-tulisan. Tidak ada partai seproduktif PKI kala itu, di masa-masa percetakan membutuhkan cukup banyak biaya. Selain koran yang beredar setiap hari seperti Harian Rakyat, PKI juga menerbitkan jurnal berisi tulisan-tulisan ilmiah, pamflet-pamflet dan banyak buku. Tiap organisasi massa underbouw PKI pun memiliki penerbitannya sendiri untuk merilis tulisan-tulisan menggunakan bahasa pengantar yang tegas dan mudah dipahami oleh para kader.

Di dalam periode tahun 1960-an, PKI selalu menyatakan bahwa kadernya berjumlah jutaan. Mereka terdiri atas lapisan masyarakat bawah, di dalamnya terdapat buruh, petani, nelayan dan kaum miskin kota yang terdorong minat atas ideologi Komunis. Ketertarikan tersebut dilatarbelakangi karena penderitaan rakyat dalam kehidupan ekonomi masa Demokrasi Terpimpin masih sangat nampak, sehingga PKI adalah jalan bagi mereka yang hendak menyandarkan impian untuk hidup adil dan berkecukupan. 
Sejak PKI tampilsebagai partaipemenang Pemilutahun 1955, pengaruh politiknya semakin kuat. Setelah peristiwa 1 Oktober 1965, hal yang pertama kali dilakukan oleh militer ialah melakukan perampasan sejumlah arsip-arsip partai. Kini melalui Arsip Nasional dokumen itu terbuka bagi publik. Dari seluruh arsip yang ada, sebagian dokumen menyimpulkan adanya laporanlaporan kegiatan pendidikan yang dilakukan oleh PKI untuk para kadernya. Inilah kunci keberhasilan PKI meraih jumlah massa yang besar.

Melalui arsip-arsip partai juga didapati hasil riset yang dilakukan oleh PKI di tingkat-tingkal lokal. Hasil riset menggambarkan kondisi geografis menentukan perbedaaan konteks sosial yang ada dalam masyarakat Indonesia. Dalam berpolitik pun langkah-langkah yang bertujuan mengorganisir sebuah organisasi diambil dalam strategi-strategi tertentu. Isu yang diangkat oleh PKI di setiap komite tingkat lokal pun berbeda. Basis massa di beberapa komite pun tidak terbatas hanya pada buruh dan petani saja. Di Jakarta, kader-kader PKI juga menyerap kalangan pedagang dan supir angkutan.

Arsip-arsip yang kini dibuka untuk publik menawarkan sebuah pandangan baru bagi masyarakat dalam memahami sejarah PKI secara lebih menyeluruh. Untuk itu, melalui tulisan ini saya ingin memanfaatkan arsip yang selama masa Orde Baru ditutup rapat, sehingga dapat menghasilkan pengetahuan masyarakat mengenai PKI yang tidak hanya bersumber pada satu arah.

Tulisan ini akan bertumpu pada data-data yang tersusun dalam daftar Inventaris Arsip Komando Operasi Tertinggi (KOTI) Tahun 1963-1967. Saya memilih arsip yang tertuju pada aktivitas PKI di tingkat lokal, yaitu Jakarta. Pemilihan Jakarta sebagai subjek tulisan ini karena menurut arsip PKI tidak hanya menjadikan Jakarta sebagai konsentrasi kekuatan politik nasional. Melalui Comite Djakarta Raya (CDR), PKI mampu membangun kekuatan politik berbasis isu-isu lokal yang dapat memberikan gambaran berbeda mengenai konteks sosial masyarakat Jakarta didasarkan pada pandangan umum.

Penelitian ini sekaligus ingin menjelaskan bahwa Jakarta tidak hanya menjadi lokasi isu-isu politik praktis bersemi, sekaligus hendak menunjukan bahwa masyarakat Jakarta juga memiliki keresahan yang sama dengan daerah lainnya-baik di kota kecil ataupun desa-mengenai persoalan memenuhi kebutuhan hidup. Maraknya penggusuran di masa Demokrasi Terpimpin serta bencana kebakaran yang sering terjadi di beberapa pemukiman acap kali membawa penderitaan bagi rakyat. Di tengah kesulitan-kesulitan ini, PKI hadir sebagai sebuah partai yang tampil beda dibandingkan dengan Partai Nasional Indonesia (PNI) yang didominasi oleh borjuasi perkotaan. Mereka (borjuasi perkotaan) dengan akses ekonomi yang begitu luas mampu melakukan kontrol terhadap aspirasi politik yang ada di Jakarta. Oleh karena itu, PKI CDR dituntut lebih terampil lagi dalam berpolitik dan 
memahami komunisme sebagai sebuah usaha membebaskan masyarakat dari ketertindasannya.

\section{Lapangan Gerakan: Tinjauan PKI Comite Djakarta Raya atas Masyarakat Jakarta}

Jakarta memiliki arti yang sangat penting bagi PKI. Sebagai pusat politik nasional, Jakarta diharapkan mampu menjadi panggung utama unjuk kekuatan-kekuatan yang dibangun oleh PKI. Di bawah kepemimpinan Aidit, di tahun 1950 PKI melakukan konsolidasi dan pembenahan partai. Dari soal organisasi sampai dengan proses ideologisasi kader-kadernya, begitu pula dengan pembenahan organisasi Comite Djakarta Raya (CDR).

Putusan pleno CC PKI bulan Oktober 1953 menghasilkan perlunya pembagian daerah Jawa Barat menjadi dua daerah besar yaitu, Jawa Barat dan Jakarta Raya. Hal ini mempertegas bahwa PKI telah menganggap Jakarta mempunyai kedudukan penting sebagai ibukota, sebagai tempat pusat partai-partai dan organisasi, sebagai tempat kedudukan pemerintah pusat dan sebagai tempat berkuasanya modal monopoli asing. Selain itu, PKI juga melihat arti penting lainnya, Jakarta sebagai kota yang penduduknya sebagian besar terdiri dari kaum buruh, kaum terpelajar, kaum borjuis kecil perkotaan dan sebagian kecil dari kaum tani.

Melalui hasil pleno ini pula CC PKI memberikan putusan kepada Comite Djakarta Raya untuk mengadakan perluasan lingkup anggota sebanyak lima kali dari jumlah yang ada sejak enam bulan. Keputusan yang diberikan oleh CC kepada CDR adalah bagian dari kerja partai dalam melakukan konsolidasi. Bagi PKI, Jakarta adalah pintu keluar masuknya bahan-bahan mentah dan juga barang-barang yang berasal dari produksi modal besar asing, terutama dengan adanya pelabuhan Tanjung Priok. Di samping itu, Jakarta juga pusat aktivitas kekuatan-kekuatan reaksi.

Dalam upaya melakukan konsolidasi di lapangan organisasi-berupa perluasan kaderisasi, CDR mendorong anggota-anggota partai untuk memahami kondisi sosial Jakarta melalui riset. Upaya tersebut menunjukan bahwa PKI berniat serius dalam memantapkan dirinya menuju sebuah organisasi modern, melampaui partai-partai lain yang tidak banyak melakukan kegiatan riset. Kegiatan ini menunjukan bahwa sebagai sebuah organisasi PKI memiliki tingkat kedisplinan tinggi dan sangat sistematis. Sebelum anggota CDR melakukan riset ke lapangan, CC PKI membuat lembaran petunjuk-petunjuk bagi para petugas riset. Berdasarkan petunjuk, setiap petugas riset harus berkomitmen menjalankan tugasnya dengan berpedoman pada semangat "tiga sama": sama makan, sama bekerja dan sama tidur.

Melalui semangat "tiga sama", para kader diharapkan untuk memahami "pergerakan" tidak hanya sebagai sebuah cita-cita namun juga sebagai 
"kenyataan". Partai mendorong pemikiran ke arah mereka agar komunisme tidak hanya berhenti pada tataran teoritis mengenai capaian akan hidup berkeadilan, tetapi juga sebuah persentuhan langsung dengan konteks ketertindasan masyarakat. Melalui semangat sama tidur, para petugas riset dianjurkan menginap di rumah warga kota yang miskin. Mereka juga mesti sama bekerja, mengerjakan apa yang dilakaukan oleh warga. Kemudian sama makan, memakan apa yang biasa di makan oleh mereka.

Melalui dokumen hasil riset borjuasi kecil kota terutama kaum miskin kota di Jakarta Raya,2 tergambarkan bahwa kondisi sosial Jakarta sangat kompleks. Berdasar hasil sensus 1964 jumlah penduduk Jakarta mencapai 2.906.533 jiwa. Jumlah tersebut terbagi dalam komposisi 1.480 .711 jiwa penduduk pria dan 1.425 .762 jiwa penduduk wanita. Penduduk asli Jakarta menduduki posisi lebih sedikit, yaitu 51 persen dari penduduk lainnya yang berasal dari Jawa Barat, Jawa Tengah, Jawa Timur, Yogyakarta, luar Jawa dan warga asing. Rincian penduduk Jakarta hasil sensus 1961 berdasar pada tingkat pendidikan dapat dilihat pada data di bawah:

\begin{tabular}{|c|c|}
\hline Sekolah Rakyat hanya sampai 3 Tahun Saja & $\begin{array}{l}\text { Dari umur } 10 \text { tahun ke atas, pria: } 227.773 \text {, } \\
\text { wanita: } 158.220 \text {, total: } \mathbf{3 8 5 . 9 9 3}\end{array}$ \\
\hline Tamatan Sekolah Rakyat & Pria: 284.318, wanita: 162.750, total: 447.068 \\
\hline Tamatan SMP/SMA & Pria: 111.074, wanita: 53.327, total: 164.401 \\
\hline Tamatan Kejuruan Pertama/Atas & Pria: 44.189, wanita: 21.750, total: 65.939 \\
\hline Tamatan Akademi/Perguruan Tinggi & Pria: 13.882, wanita: 3.013 , total: $\mathbf{1 6 . 8 9 5}$ \\
\hline Yang Masih Sekolah & $\begin{array}{l}\text { Dari umur lima tahun ke atas, pria: } 276.611 \text {, } \\
\text { wanita: } 220.133 \text {, total } 496.744\end{array}$ \\
\hline Yang Buta Huruf & $\begin{array}{l}\text { Dari umur lima tahun ke atas pria dan wanita: } \\
771.590\end{array}$ \\
\hline Pengangguran & $\begin{array}{l}\text { Dari umur } 15 \text { tahun ke atas, pria: } 50.210 \text {, } \\
\text { wanita: } 23.096 \text {, total: } 73.306\end{array}$ \\
\hline
\end{tabular}

Meskipun berkedudukan sebagai pusat aktivitas nasional, Jakarta masih dihadapi pada masalah-masalah sosial serius salah satunya tentang kualitas manusia berdasarkan tingkat pendidikannya. Hal ini menjadi catatan penting bagi pemerintah pusat dan kota Jakarta untuk segera meningkatkan taraf sosial. Permasalahan yang sering kali ditemui di tengah-tengah sulitnya akses pendidikan bagi masyarakat Jakarta ialah tentang jumlah sekolah di Jakarta yang tidak mampu menampung para peserta didiknya. Pada tahun 1952, anggota Badan Pemerintah Harian merangkap Ketua Seksi Pendidikan dan Pengajaran sekolah-sekolah rakyat Jakarta, Sardjono menjelaskan bahwa rencana pembuatan 80 fasilitas Sekolah Rakyat (SR)

2) Laporan ini dibuat oleh tim riset CDR pada 26 September 1964. Riset berikutnya dilakukan pada tahun 1965 dengan memakan waktu selama satu bulan, mulai tanggal 20 Januari sampai 20 Februari 1965. 
untuk menampung 50.000 anak harus rancang kembali. Pemerintah hanya mampu melaksanakan pembuatan sebanyak 21 rumah SR, selebihnya tidak terpenuhi karena tidak adanya tanah (Harian Rakyat, 5 Mei 1952). Pada prakteknya upaya meningkatkan kualitas sumber daya manusia yang diukur dari tingkat pendidikan ini tidak memuaskan.

Di saat pemenuhan pendidikan tidak terpenuhi, jenis-jenis pekerjaan masyarakat Jakarta mulai beragam. Selain menjadi pegawai negeri sipil, jumlah persebaran buruh yang bekerja di berbagai lapangan menurut hasil sensus 1961 ada 17 klasifikasi, antara lain: pertanian atau peternakan sebanyak 37.008, perikanan 6.844, industri pangan 13.045, industri tekstil 7.944, pabrik pakaian 34.924, industri meubel 5.380, percetakan 12.121, pabrik kulit atau barang-barang kulit 2.875, industri barang-barang karet 3.034, industri kimia 14.786, pabrik atau perbengkelan 14.049, pabrik alat-alat angkutan 18.929, bangunan 70.838, listrik/gas/air/uap 4.440, perdagangan/bank/asuransi 221.562, pengangkutan/perhubungan 109.533 dan sektor jasa 293.855. Total yang buruh yang bekerja pada 17 sektor pekerjaan ada 880.855 jiwa.

Di tengah keadaan masyarakat Jakarta yang demikian, PKI CDR menyadari bahwa lapisan masyarakat yang mudah terguncang adalah buruh, kaum miskin kota, nelayan, petani dan pemuda. Kelompok terbesar diisi oleh buruh dan kaum miskin kota, separuhnya lagi adalah petani yang banyak tersebar di Pasar Rebo. Berdasarkan laporan yang dibuat oleh Grup Koperasi Konsumsi, Barisan Tani Indonesia (BTI) pada 1 Agustus 1964, menyatakan bahwa ada perubahan yang terjadi pada masyarakat tani Pasar Rebo. Kecamatan Pasar Rebo terdiri dari 27 kelurahan dengan 130.000 jiwa penduduk mengalami perkembangan dari masyarakat tani menjadi masyarakat setengah tani. Mereka bertani mengikuti siklus musim, bercocok tanam apabila datang musim tanam dan panen, di luar musim itu mereka harus hidup dari pekerjaan lain seperti membuat kolam ikan, berkebun dan berdagang. Di tambah lagi, pendidikan bagi masyarakat Pasar Rebo masih sangat terbatas. Separuh penduduk usia tua masih buta huruf, sedangkan usia muda atau produktif kebanyakan tidak mampu menyelesaikan sekolahnya.

Riset yang dilakukan pada tahun 1964 menyebar tim riset di empat wilayah seperti Tanjung Priuk, Mangga Dua, Kebayoran Baru dan Pasar Rebo. PKI CDR menganalisis bentuk-bentuk penghisapan yang dialami oleh kaum miskin kota pada umumnya berasal dari "penghisapan" para juragan. Di satu pihak mereka mengalami penghisapan yang bersifat kapitalistis dengan harus bekerja keras menjual barang dagangan dan memberikan keuntungan besar kepada juragan. Di sisi lain, mereka mengalami penghisapan yang bersifat feodalistis dengan masih harus melakukan pekerjaan-pekerjaan tambahan untuk keperluan juragan. Bentuk-bentuk pekerjaan tambahan itu seperti menimba air, membersihkan perabotan milik juragan, mengantarkan 
anak juragan ke sekolah dan menjaga keamanan rumah juragan. Mereka harus bekerja keras untuk memenuhi kebutuhan hidup di saat waktu istirahat hanya 3 atau 4 jam dalam sehari. Selain itu, mereka juga terikat perjanjian dengan memilih sistem menjual barang dagangan menggunakan sistem borongan (habis atau tidaknya barang dagangan adalah tanggungan penjual) atau sistem bukan borongan (jikalau barang dagangan tidak habis dapat dikembalikan dan diperhitungkan dengan juragan).

Karena tidak dapat mencukupi keperluan hidup sehari-hari, kaum miskin kota mencari jalan lain untuk memenuhi kebutuhan hidupnya dengan meminjam uang dengan bunga yang besar kepada rentenir, bank keliling atau bank pasar. Di samping itu pula, kaum miskin kota yang berdagang harus dihadapkan pada berbagai macam pungutan. Mereka juga sering menghadapi tekanan penggusuran yang sering dilakukan dengan menyasar para pedagang kecil (Harian Rakyat, 27 Juli 1959).

Akibat dari kemerosotan ekonomi yang terjadi di Jakarta, memunculkan gelandangan yang bersumber dari para pengangguran. Di tahun 1952, terdapat 200.000 pengangguran yang disebut kaum djembel (Harian Rakyat, 28 Februari 1952). Besarnya jumlah pengangguran di Jakarta ini mendorong pemerintah kota untuk menjadikan Pasar Rebo dan Lenteng Agung sebagai daerah-daerah baru tempat tinggal orang-orang terlantar. Menurut D.M. Januar yang menjabar Ketua Panitia Pemindahan dan Persebaran Penduduk, kaum terlantar yang ada di jalan-jalan umum, pasar-pasar dan kolong jembatan akan dipindahkan ke dua daerah tersebut dan didorong untuk bercocok tanam (Harian Rakyat, 14 Mei 1952).

Dari sudut kepentingan riset-riset yang diupayakan PKI CDR, pihak-pihak yang dicatat melakukan penghisapan terhadap kaum miskin adalah para kapitalis birokrat (kabir). Mereka dinilai mempunyai sifat menyalahgunakan kekuasaan untuk meraup kekayaan negara. Mereka juga mempunyai hubungan yang erat dengan tuan tanah dan imperialis. Selain kabir, penghisapan yang dirasakan oleh kaum miskin kota di Jakarta dilakukan oleh bandit-bandit pasar, lintah darat dan tuan tanah.

\section{Suara "Merah" Ibukota}

Situasi Jakarta pada awal tahun 1950-an sangat menggambarkan kondisi sebuah negara yang masih berusia sangat muda. Jakarta mengalami ketidakstabilan politik dan kemerosotan ekonomi. Kekerasan hadir dimana-mana, baik di pinggiran maupun pusat kota. Berita mengenai pencurian tidak pernah berhenti hadir dalam surat-surat kabar. Pada Mei 1952, sebuah toko emas dan berlian Beeger Van Kempen di Jalan Nusantara mengalami kerugian sebesar 120.000 karena dirampok (Harian Rakyat, 23 Mei 1952). Dalam hitungan hari, serentetan kasus perampokan kembali terjadi di Jakarta. Di Sawah Besar, seorang tionghoa bernama T. Han Tja dirampok oleh delapan 
orang bersenjata pistol dan tajam sehingga mengalami kerugian 71.800 rupiah. Di depan gedung kesenian, Jalan Pasar Baru, terjadi perampokan oleh dua orang bersenjata tajam atas pedagang warung yang kehilangan sepeda dan barang-barang dagangannya. Di Jalan Pejagalan, enam penjahat bermotor berhasil merampok cincin emas milik Mo Pang An (Harian Rakyat, 26 Mei 1952). Melalui sejumlah riset Comite Djakarta Raya yang dibentuk sejak tahun 1950 dengan Peris Pardede sebagai sekretaris umum,3 para kader PKI berpandangan bahwa kondisi tersebut diakibatkan semakin banyaknya pengangguran di kota-kota dan desa-desa. Mereka tidak menahu apa yang harus diperbuat hingga menghidupi diri dengan menempuh caracara hidup yang bertentangan dengan kaidah seperti menjadi pencuri, perampok, pengemis, pelacur dan lain-lain. 4

Pada September 1955, harga garam dan minyak mengalami kenaikan. Antrian masyarakat terlihat di Jalan Pegangsaan Barat untuk mendapatkan garam dan minyak (Harian Rakyat, 16 September 1955). Dalam keadaan seperti ini, PKI meyakini bahwa rakyat harus dibangun kesadaran politiknya. Untuk itu, dalam program kerjanya PKI Comite Djakarta Raya menargetkan sampai pada akhir Desember 1956 partai harus sudah selesai mendengarkan suara massa untuk menentukan program politik. Partai juga sudah harus membentuk panitia-panitia aksi. 5

Dalam lingkup nasional, masalah-masalah ekonomi dan sosial yang dihadapi bangsa Indonesia setelah pendudukan Jepang dan revolusi sangatlah besar. Di Jawa, produksi beras per kapita sedikit menurun dalam kurun tahun 1950-1960, oleh karenanya sejumlah besar impor pangan masih diperlukan. Pertanian banyak menyerap tenaga kerja baru dengan membagi pekerjaan kepada sejumlah buruh yang jumlahnya meningkat terus. Tetapi dengan menurunnya kepemilikan lahan, banyak keluarga petani tidak lagi memiliki lahan yang cukup untuk menafkahi hidup dan harus mencari pendapatan dengan menjadi buruh upahan. Banyak dari mereka berduyunduyun ke kota-kota yang tengah tumbuh pesat. Antara tahun 1945 sampai 1955, jumlah penduduk Jakarta meningkat dua kali lipat menjadi 1,8 juta jiwa dan bertambah lagi menjadi 2,9 juta jiwa pada tahun 1961 (Ricklefs, 2010: 494-495). Sekretaris komite seksi PKI Tanah Abang, Hasan Raid (2001: 130) menyatakan masalah penggusuran rumah penduduk yang dilakukan oleh pemerintah kota merupakan akibat dari pesatnya pertumbuhan penduduk di Jakarta.

3) Keterangan ini didapat pada artikel yang memaparkan biografi singkat Peris Pardede pada Harian Rakyat yang terbit pada 8 September tahun 1955.

4) Terpapar dalam laporan riset PKI Comite Djakarta Raja yang dibuat pada 26 September 1964.

5) Program kerja ini dibuat oleh Comite Daerah Djakarta Raya sampai akhir tahun 1957. 
Bertambahnya jumlah penduduk merupakan bagian konsekuensi dari usaha pembangunan, dan darinya timbul dampak-dampak sosial. Hal ini nampak saat diberlakukannya aturan tentang perubahan lalu lintas secara besar-besaran pada tahun 1954. Penertiban terhadap kendaraan becak dan oplet dilakukan di sepanjang Jalan Gajah Mada serta dipersimpangan Senen Raya. Akibat dari kebijakan ini, saat hendak mencari penumpang para pengemudi becak dan oplet harus melalui jalan yang sangat jauh hingga menyebabkan kenaikan ongkos biaya bahan bakar dan jumlah penumpang berkurang.

Kebijakan penertiban memicu terjadinya pemogokan serentak selama dua hari, praktis melumpuhkan sebagian besar transportasi dalam kota di Jakarta. PKICDR mendukung aksi yang dilakukan oleh para buruh kendaraan ini dan membenarkan tuntutan untuk mencabut peraturan lalu lintas yang telah dibuat. PKI beranggapa jika peraturan lalu lintas ini tetap diteruskan, tingkat hidup kaum buruh kendaraan oplet akan merosot. Di samping itu, kerugian akan menimpa golongan rakyat yang lainnya. Kaum buruh dan pegawai negeri yang tidak punya kendaraan sendiri terpaksa mengeluarkan ongkos lebih untuk mencapai tempat-tempat pemberhentian oplet lainnya. Kerugian juga akan dirasakan oleh para pengusaha oplet-dimana PKI CDR menganggap bahwa mereka adalah borjuasi nasional yang harus didukungapabila kaum buruhnya tidak bisa memenuhi setoran. Pernyataan PKI CDR pada 11 Agustus 1954 menyerukan kepada kaum buruh kendaraan oplet agar menarik keikutsertaan pelajar untuk memeriksa kelemahan-kelemahan peraturan resmi lalu lintas dan memperkuat solidaritas kaum buruh.

Menjelang pemilu 1955 harga kebutuhan pokok di Jakarta melambung tinggi. Rakyat Jakarta untuk kesekian kalinya mengalami kesulitan membeli minyak tanah di warung-warung dan toko-toko. Kondisi ini langsung ditanggapi oleh PKI CDR. Kebutuhan pokok adalah akses ideologis bagi partai untuk masuk ke dalam kesadaran politik rakyat agar tergerak untuk bergorganisasi dan menghimpun diri bersama partai. Dalam pernyataannya, PKI CDR menuding bahwa PERBUM telah memainkan ketersediaan minyak tanah dan bensin di pasaran dengan dalih untuk kebutuhan konferensi AsiaAfrika. PERBUM lantas memberikan penjelasan bahwa BPM yang membuat sulit peredaran minyak dengan mengurangi pengeluaran minyak. BPM dengan sengaja menutup instalasi yang ada di Indramayu, Tegal, Bogor, Semarang, Purwakarta, Cianjur dan Garut.

PKI CDR berpendapat bahwa tindakan BPM sangat berbahaya dan langsung merusak kehidupan rakyat banyak. Menurut pernyataan CDR pada 7 April 1955, selama BPM masih berkuasa atas sumber minyak dan alat-alat distribusinya, maka kejadian seperti ini akan tetap terulang. Oleh karena itu, CDR memobilisasi rakyat untuk menuntut kepada pemerintah supaya mengambil tindakan tegas terhadap BPM. Ini merupakan bagian 
dari sikap nasionalis PKI untuk mewujudkan loyalitasnya terhadap Sukarno dan rakyat.

Pada September 1955 berlangsung Pemilihan Umum untuk memilih anggota DPR. PKI menjadi salah satu dari empat besar. Beberapa waktu sesudah pemilu, PKI CDR menyelenggarakan konferensi. Selain membahas soal pemilu, acara ini juga bertujuan memilih komite yang baru. Satu tradisi di lingkaran PKI, setiap orang yang mencalonkan seseorang untuk duduk dalam kepimpinanan harus disertai dengan alasan kelebihan dan kekurangannya. Dari perdebatan soal kelebihan dan kekurangan tersebut terpilihlah Sudadi sebagai pimpinan CDR yang baru. Di bawah kepemimpinan Sudadi, pada tahun 1958 CDR menganggap perlu untuk mempunyai terbitan khusus bagi kader komunis di Jakarta. Usulan ini menghasilkan penerbitan majalah Suara Ibukota setiap satu bulan sekali. Semula yang ditetapkan menjadi penanggung jawab adalah Hardjito, namun kemudian CDR menetapkan Hasan Raid sebagai penggantinya (Hasan Raid, 2001: 143).

Meski berhasil memasuki parlemen, PKI tidak menyurutkan suaranya di jalanan untuk membela masyarakat yang tertindas. Pada 13 Desember 1959, PKI CDR seksi Salemba mengirimkan surat kepada Peperda Jakarta berhubungan dengan pembakaran yang dilakukan oleh 30 orang aparat termasuk dua orang tentara terhadap gubuk-gubuk di Rawasari. Di dalam surat terbuka tersebut PKI CDR seksi Salemba mempertanyakan mengenai kebijaksanaan Peperda dalam melakukan pembersihan terhadap gubukgubuk liar (Suara Ibukota, 1 Januari 1960).

Selain aksi-aksi politik, PKI di Jakarta terus mendorong lahirnya gerakan berbasis sosial melalui kegiatan-kegiatan amal. Hal ini dibuktikan oleh rangkaian kerja bakti di Kampung Teluk Gong pada 20 Desember 1959 yang diselenggarakan PKI CDR seksi Penjaringan. Kerja bakti ini bertujuan menunjukan pengabdian partai kepada rakyat (Suara Ibukota, 2-15 Januari 1960). Selain itu, PKI CDR juga menyerukan kepada segenap kaum komunis di ibukota untuk terlibat dalam aksi yang diberi judul "Adakan 1001 Kegiatan Setia Kawan Untuk Korban Kebakaran di Sawah Besar”. Di samping mengajak rakyat, salah satu pimpinan CDR, Anwar Sanusi menyatakan ikut berduka cita atas terjadinya kebakaran besar di Sawah Besar pada hari Sabtu sore tanggal 26 Mei 1962. Satu hari kemudian, CDR menghimpun sumbangan untuk diberikan kepada para korban kebakaran berupa 500 liter beras dan $40 \mathrm{~kg}$ ikan. Cara-cara ini dianggap tepat oleh CDR untuk menghimpun solidaritas dan kesadaran politik rakyat Jakarta, salah satu alasannya karena Jakarta memiliki karakter masyarakat yang heterogen dengan sifatnya yang pragmatis.

CDR mulai mendorong musyawarah untuk merumuskan program politik pada tahun 1961. Musyawarah tersebut menyerap peran serta elemen-elemen organisasi masyarakat Jakarta yang berada di bawah 
pengorganisiran PKI CDR, mereka terdiri buruh, petani, kaum miskin kota dan pemuda rakyat. Musyawarah yang digelar di Gedung SBKA Manggarai ini dihadiri 750 orang dari pimpinan organisasi massa serta beberapa perwakilan anggota.6 Suara-suara keresahan rakyat ibukota dihimpun dan nantinya akan dijadikan pijakan untuk dibawa ke pemerintah dengan berbagai jalan, salah satunya demonstrasi.

Musyawarah menghasilkan berbagai macam tuntutan. Pertama, mengenaipermasalahan banjur diibukota, peserta musyawarah menyuarakan agar pemerintah pusat dan kota segera membuat proyek-proyek pencegahan banjir. Kedua, tentang distribusi kebutuhan pokok, para peserta menuntut pemerintah daerah untuk mengawasi alokasi distribusi dan melibatkan peran rakyat untuk mengontrol tindak korupsi. Ketiga, peserta musyawarah mengajak rakyat Jakarta untuk mendukung pembebasan Irian Barat dari tangan kaum imperialis. Keempat, mengenai permasalahan angkutan dalam kota, para peserta menuntut agar jumlah bis milik pemerintah (DAMRI dan PPD) diperbanyak dan rutenya disempurnakan. Selain itu, DAMRI dan PPD diminta menyediakan angkutan khusus untuk keperluan pedagang-pedagang kecil dari pinggir kota seperti Pasar Rebo, Pasar Minggu, Kebayoran Lama, Cengkareng dan Klender. Kelima, para peserta menuntut pemerintah untuk menyediakan tempat berdagang yang layak bagi pedagang kecil.

Memasuki tahun 1960-an kondisi masyarakat Jakarta dalam memenuhi kebutuhan hidup semakin sulit. Harga beras dan kebutuhan pokok lainnya terus meningkat. Sesungguhnya keseulitan ini tidak hanya terjadi di Jakarta, bahkan di daerah kondisinya lebih parah dibandingkan ibu kota. Sekretaris CDR Anwar Sanusi menyatakan bahwa pusat dari kesalahan ini bukan Sukarno. Permasalahan beras bukan permasalahan yang berdiri sendiri, namun disebabkan keberadaan birokrat yang tidak kompeten.

Anwar Sanusi menuding bahwa birokrat merupakan sumber kesalahan dalam mengurus persoalan kebutuhan pokok rakyat. Diduga terdapat penyalahgunaan wewenang yang dilakukan oleh kapitalis birokrat, sebab di tengah kehidupan rakyat kecil yang menderita banyak pula munculnya "Orang Kaya Baru”. Di saat yang bersamaan, jatah beras bulan Desember 1962 akan dihapuskan dan jatah beras untuk pegawai negeri akan diganti dengan uang. Anwar Sanusi menyatakan bahwa ini akan menimbulkan kemarahan rakyat. Dia mendesak agar semua organisasi massa bersatu untuk menuntut dikembalikannya jatah beras, sebab urusan perut tidak bisa menunggu.7

Sejak bulan Juni 1962 harga beras yang dijual di pasar-pasar mengalami kenaikan dari 3,90 rupiah menjadi 9,70 rupiah per liter. Kenaikan harga tiga

6) Hasil musyawarah ini diterbitkan oleh Suara Ibukota dalam brosur berbentuk buku saku yang diberi judul "Usul Program Bersama Untuk Menjadikan Djakarta Raya Kebanggaan Nasional”.

7) Pernyataan ini diberi judul oleh Anwar Sanusi sebagai "Beras Sekarang Juga”, diterbitkan oleh Suara Ibukota dalam bentuk buku saku pada tahun 1962. 
kali lipat mendorong PKI CDR melayangkan surat protes kepada Gubernur pada 17 Juni 1962. Di dalam surat mereka menyatakan apabila harga beras tidak kunjung turun dalam waktu yang singkat, CDR mengusulkan supaya tiap penduduk kota Jakarta dapat membeli beras dengan harga pemerintah sebanyak yang diperlukan, sehingga rakyat tidak harus membeli dari pasarpasar yang harganya mengalami kenaikan 150 persen.

Sampai pada tahun 1965 aktivitas politik CDR berkutat pada isu-isu seputar kebutuhan hidup. Hal ini menunjukan bahwa sekalipun Jakarta memiliki kedudukan sebagai pusat politik nasional, CDR memilih untuk berpolitik dari bawah ke atas.

\section{Kesimpulan}

Kontestasi politik di Jakarta tidak selalu dapat dimaknai dengan perebutan hegemoni penguasaan wacana nasional. Meski dalam periode politik Indonesia 1950-1965 pertarungan wacana terjadi di antara tiga kekuatan besar yaitu nasionalis, agama, dan komunis (Nasakom). Hal itu hanya diorganisir oleh pimpinan pusat organisasi-organisasi tiga kekuatan besar di Indonesia yang pusat organisasinya berkedudukan di Jakarta.

Aktivitas politik PKI Comite Djakarta Raya membuktikan bahwa sebagai sebuah lokalitas-selain sebagai ibukota-Jakarta juga memiliki kekhususan yang sama dengan tempat lainnya. Ada karakter sosial tersendiri yang nantinya akan menentukan jalan politik sebuah ideologi. Karena Jakarta memiliki basis sosial yang heterogen, pilihan untuk menggerakan massa pun diambil oleh CDR dengan program yang mesti mendapat pembaharuan terus-menerus melalui kegiatan kritik-otokritik.

Bila basis massa PKI di sebagian besar pulau jawa adalah petani dan buruh pabrik, CDR memiliki basis massa kaum miskin kota-yang nantinya kota lain seperti Surabaya dan Semarang juga memakai logika sama dengan istilah yang dipakai CDR. Kaum miskin kota sesungguhnya tidak secara detail dijelaskan dalam kamus kaum komunis di dunia. Namun demikian, keberadaan kaum miskin kota disebabkan oleh roda kapitalisme.

PKI Comite Daerah Jakarta Raya menyadari ada sifat khusus dari keberadaan kaum miskin kota. Di satu sisi kaum miskin kota sudah memerlukan pimpinan aksi untuk ketertindasannya, sedangkan di sisi lain kaum miskin kota sulit untuk ditarik ke dalam gerakan revolusioner. Hal ini dikarenakan keterbelakangan atau kurangnya kesadaran kaum miskin kota dalam persoalan-persoalan organisasi dan politik. Untuk itu, CDR terus mendorong kesadaran kaum miskin kota melalui aksi-aksi politik. 


\section{Referensi}

\section{Arsip}

Inventaris Arsip Komando Operasi Tertinggi Tahun 1963-1967:

246, Tuntutan Secom PKI Jakarta.

252, Laporan Sidang Pleno CC PKI di Jakarta.

259, Makalah Comite PKI Jakarta.

1233, Surat Kabar Suara Ibukota.

1087, Usul Program Bersama dalam Suara Ibukota.

1134, Pernyataan Anwar Sanusi dalam Suara Ibukota.

1135, Pernyataan Sekretaris Pertama Comite PKI Jakarta.

1278 , Berita organisasi tentang ibukota.

265, Laporan mengenai perjuangan buruh Jakarta.

273, Berkas mengenai plan tiga tahun PKI Jakarta.

339, Laporan dewan harian Comite PKI Jakarta.

369, Surat dari PKI Jakarta ke Gubernur.

374, Pokok keputusan Sidang Pleno Comite PKI Jakarta.

424, Berkas mengenai gerakan turba PKI.

488, Pernyataan PKI Jakarta soal minyak.

574, Program kerja Comite PKI Jakarta.

557, Laporan PKI Jakarta tentang aksi-aksi di ibukota.

484, Berkas riset kemiskinan PKI Jakarta.

\section{Buku}

Feith, Herberth. Soekarno-Militer dalam Demokrasi Terpimpin. Jakarta: Pustaka Sinar Harapan, 1995.

Feith, Herberth. Pemilihan Umum di Indonesia 1955. Jakarta: KPG, 1999.

Lev, Daniel S., et.al. Menjadikan Indonesia: Dari Membangun Bangsa Menjadi Membangun Kekuasaan. Jakarta: Hasta Mitra, 2008.

Mc.Vey, Ruth. Mengajarkan Modernitas: PKI Sebagai Sebuah Lembaga Pendidikan. Pustaka IndoPROGRESS, 2016.

Mortimer, Rex. Indonesian Communism Under Sukarno: Ideologi dan Politik 1959-1965. Yogyakarta: Pustaka Pelajar, 2011

Hasan Raid. Pergulatan Muslim Komunis: Otobiografi Hasan Raid. Yogyakarta: Syarikat, 2001

Ricklefs, M.C. Sejarah Indonesia Modern 1200-2008. Jakarta: Serambi, 2008.

Satriono Priyo Utomo. Aidit, Marxisme-Leninisme dan Revolusi Indonesia. Yogyakarta: IBC, 2016.

\section{Surat Kabar}

Harian Rakyat, 5 Mei 1952

Harian Rakyat, 27 Juli 1959

Harian Rakyat, 28 Februari 1952

Harian Rakyat, 14 Mei 1952

Harian Rakyat, 8 September 1955

Harian Rakyat, 23 Mei 1952

Harian Rakyat, 26 Mei 1952

Harian Rakyat, 16 September 1955

Suara Ibukota, 1 Januari 1960

Suara Ibukota, 2-15 Januari 1960 